
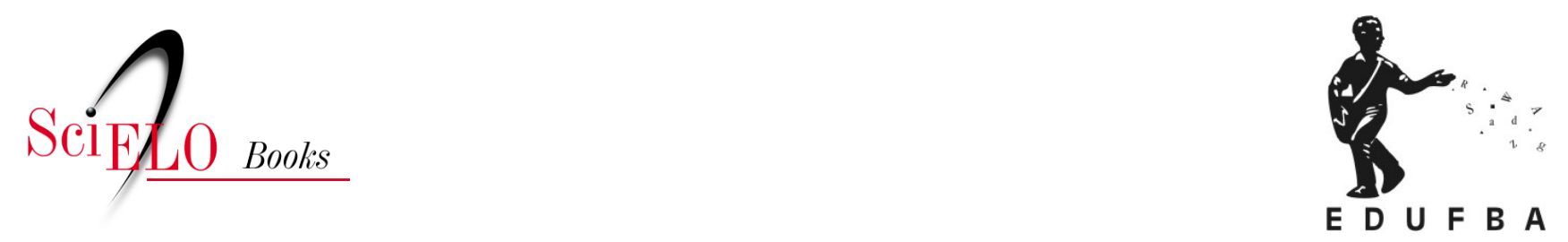

\title{
Parte II - Propostas de ensino \\ Cotas raciais, genes e política uma questão sociocientífica para o ensino de ciências
}

\author{
Thiago Leandro da Silva Dias \\ Kelly Meneses Fernandes \\ Juanma Sánchez Arteaga \\ Claudia Sepúlveda
}

\section{SciELO Books / SciELO Livros / SciELO Libros}

DIAS, T.L.S., FERNANDES, K.M., ARTEAGA, J.S., and SEPÚLVEDA, C. Cotas raciais, genes e política uma questão sociocientífica para o ensino de ciências. In: CONRADO, D.M., and NUNES-NETO, N.

Questões sociocientíficas: fundamentos, propostas de ensino e perspectivas para ações sociopolíticas [online]. Salvador: EDUFBA, 2018, pp. 303-324. ISBN 978-85-232-2017-4.

https://doi.org/10.7476/9788523220174.0015. \section{International license.}

All the contents of this work, except where otherwise noted, is licensed under a Creative Commons Attribution 4.0

Todo o conteúdo deste trabalho, exceto quando houver ressalva, é publicado sob a licença Creative Commons Atribição 4.0. 


\title{
COTAS RACIAIS, GENES E POLÍTICA UMA QUESTÃO SOCIOCIENTÍFICA PARA O ENSINO DE CIÊNCIAS
}

\author{
Thiago Leandro da Silva Dias \\ Kelly Meneses Fernandes \\ Juanma Sánchez Arteaga \\ Claudia Sepúlveda
}

\section{Introdução}

A ciência não é uma atividade neutra e o seu desenvolvimento está diretamente imbricado com os aspectos sociais, políticos, econômicos, culturais e ambientais, um empreendimento que não diz respeito exclusivamente aos cientistas e possui fortes implicações para a sociedade. (GIL-PERÉZ et al., 2001; SANTOS; MORTIMER, 2001, 2002) Ao longo da história, por exemplo, é possível verificar como discursos científicos e práticas das tecnociências estiveram comprometidos com processos sociais de dominação entre povos, compondo complexas relações de poder.

Em todo o século XIX - um período marcado pelo imperialismo e guerras coloniais -, os conceitos relativos ao pensamento darwinista contribuíram para mistificar cientificamente determinadas hierarquias raciais no imaginário coletivo do mundo ocidental. (SÁNCHEZ-ARTEAGA, 2007) Existem relatos de outros casos históricos de marginalização de determinados grupos humanos fundamentada na naturalização de categorias 
de normalidade, inferioridade e superioridade em sistemas hierárquicos de indivíduos, como, por exemplo, as numerosas tentativas históricas de demonstrar a superioridade intelectual dos homens sobre as mulheres. (FEDIGAN, 1986; HARAWAY, 1991; QUEROL, 2001; SCHIEBINGER, 2000) Esses exemplos históricos de alterização ${ }^{1}$ científica mostram que a marginalização de diferentes comunidades humanas sobre bases científicas tem sido uma prática recorrente na história das ciências biomédicas. (SÁNCHEZ-ARTEAGA, SEPÚLVEDA; EL-HANI, 2013)

Os conhecimentos derivados das ciências naturais que contribuíram para criação e legitimação do conceito de raça ao longo da história, com objetivos explícitos de inferiorização, marginalização e dominação étnicas - seja na política expansionista das potências europeias do século XIX, pautada nos discursos darwinistas sobre competição inter-racial e extinção racial, ou nas políticas eugênicas do século XX - atualmente põem em questão a própria existência de raças dentro da espécie humana, a partir da investigação genética contemporânea. (PENA; BORTOLINE, 2004; SÁNCHEZ ARTEAGA; SEPÚLVEDA; EL-HANI, 2013) No entanto, essa tendência de desconstrução do conceito biológico de raça não necessariamente permite negar a existência dessa categoria como construção e realidade social e pode vincular-se a diversas perspectivas ideológicas, políticas e econômicas em torno da questão racial, como no caso da implementação de políticas de ações afirmativas em universidades brasileiras.

O debate em torno dos resultados de um conjunto de estudos da genética humana com marcadores de ancestralidade sobre a composição étnica da população brasileira, tornado público sob o título "Retrato molecular do Brasil", mostra-se relevante para as reflexões sobre o papel que o conhecimento científico-tecnológico pode exercer na conformação das relações sociais e políticas na sociedade ocidental moderna. (SANTOS; MAIO, 2004)

O estudo de autoria de Sérgio Pena e colaboradores (2000), geneticistas ligados à Universidade Federal de Minas Gerais, utiliza ferramentas da moderna genética molecular, visando reconstituir as "origens genéticas do brasileiro". ${ }^{2}$ Os resultados da pesquisa indicam, entre outros aspectos, que a amostra de indivíduos, autoclassificados como brancos, que participou do estudo, apresentava uma maior frequência de marcadores genéticos de origem africana e/ou ameríndia do que de origem europeia. Entre as impli-

1 Usamos o termo "alterização" com o significado atribuído por Sanchez-Arteaga, Sepúlveda e El-Hani (2013, p. 61), para fazer referência aos processos simbólicos de geração e construção de categorias com as quais passamos a compreender os "outros". Entendidos desta forma, esses processos podem ser considerados como intrínsecos a todo processo social, envolvidos na construção de identidade. Mas, neste caso específico da alterização científica, estamos nos referindo aos processos de nomear e etiquetar aqueles que são considerados como diferentes, "outros", desde o ponto de vista de uma comunidade hegemônica constituída por "nós", processos esses que, na maioria das vezes, implicam inferiorizar e discriminar aqueles tidos como diferentes.

2 Esses estudos buscaram, através do sequenciamento de porções do DNA mitocondrial e do cromossomo $Y$, identificar padrões de ancestralidade das matrilinhagens e patrilinhagens da população brasileira. 
cações destes resultados, encontram-se as conclusões de que os afrodescendentes são em número bem maior do que aqueles que aparentam ser por suas características físicas e, de outro lado, que muitos dos indivíduos que se identificam como negros apresentam uma proporção significativa de ancestralidade europeia. (PENA et al., 2000; SANTOS; MAIO, 2005a) Segundo Santos e Maio (2005a), o que emerge das pesquisas genéticas é a corroboração quanto à natureza mestiça da amostra de brasileiros (autoclassificados) brancos, já que a maioria (aproximadamente $60 \%$ ) apresenta marcadores genéticos indicadores de matrilinhagem de origem ameríndia ou africana.

Tais resultados desestabilizam discursos racialistas, que afirmam a existência de raça, baseados em um conjunto específico e limitado de características fenotípicas, e relativizam diversas questões sociais e políticas em torno dos parâmetros raciais de classificação e processos identitários no Brasil. Nessa conjuntura, conforme Santos e Maio (2004, p. 4), "[...] há uma forte tensão entre perspectivas, cujos ingredientes incluem raça, genes, construção de identidades coletivas, história e modalidades de interpretação do Brasil, bem como ativismo e estratégias de combate ao racismo".

O debate sobre implementação de políticas de ações afirmativas ${ }^{3}$ é um exemplo que pode indicar como conhecimentos científicos da nova genômica são apropriados ideologicamente por alguns grupos sociais e geram tensões entre demandas sociais diversas. A polêmica se dá, principalmente, no que diz respeito à definição de critérios indicados para definir quem deve ser beneficiado por tais políticas, levando em consideração a relativização e a negação do conceito de raça como categoria de distinção biológica. Por esta razão, consideramos que este tema pode dar origem a uma Questão Sociocientífica (QSC) a ser tratada no contexto do ensino de biologia.

A utilização de QSC no ensino de ciência e biologia, a partir da abordagem educacional Ciência, Tecnologia, Sociedade e Ambiente (CTSA), baseia-se no uso de conhecimentos científicos sobre temas sociais controversos, que geralmente exigem dos educandos diálogos, discussões e debates, além de um grau de raciocínio moral ou avaliação de questões éticas e posicionamento crítico no processo de tomada de decisões. (MARTÍNEZ PÉREZ; CARVALHO, 2012; ZEIDLER; NICHOLS, 2009)

As QSC apresentam, para o ensino de ciências, importantes possibilidades para trabalhar aspectos políticos, ideológicos, culturais e éticos relacionados à ciência contemporânea (MARTÍNEZ PÉREZ, 2010) e podem, ainda, promover a capacidade de posicionamento na esfera social que subsidie alguma ação sociopolítica. (HODSON, 2004) Um viés de trabalho com estes aspectos pode ser planejado a partir de controvérsias, envolvendo temáticas sobre raça, ciência e sociedade.

A abordagem de tais temáticas, a partir dessa perspectiva, relaciona-se ainda com a possibilidade de implementação de uma educação das relações étnico-raciais (BRASIL,

3 Trata-se de conjuntos de ações políticas dirigidas à correção de desigualdades raciais e sociais, orientadas para oferta de tratamento diferenciado com vistas a corrigir desvantagens e marginalização criadas e mantidas por estrutura social excludente e discriminatória. (BRASIL, 2004) 
2004, 2009) no ensino de ciências e biologia. Verrangia e Silva (2010) descrevem algumas temáticas e questões prioritárias do ponto de vista dessa diretriz educacional, como abordagens que visem analisar criticamente a utilização dos conhecimentos científicos pela mídia na discussão, por exemplo, sobre políticas públicas, como as ações afirmativas. Para realizar a crítica sugerida, podem ser promovidas atividades que identifiquem e avaliem a veiculação de conhecimentos do campo da genética molecular e de populações a respeito da variabilidade genética humana e, especificamente, os estudos sobre padrões de ancestralidade da população brasileira, baseados em marcadores gênicos, no contexto de discussões sobre as chamadas cotas raciais. (VERRANGIA, 2014; VERRANGIA; SILVA, 2010)

Diante do exposto, levantamos a seguinte questão: quais as possibilidades e os desafios em promover compreensão crítica das relações CTSA e das relações étnico-raciais, por meio da abordagem de uma QSC baseada no uso do conhecimento sobre variabilidade genética e ancestralidade genômica da população brasileira e suas implicações sociais e políticas no debate sobre cotas raciais nas universidades brasileiras? Tal necessidade de problematização sustenta o objetivo deste capítulo, o qual pretende apresentar uma QSC sobre os discursos em torno das origens genéticas da população brasileira e as políticas de ações afirmativas, discutindo meios para sua aplicação no ensino de ciências e biologia.

Para dar conta de tal objetivo, aprofundaremos algumas questões sobre a temática proposta e, em seguida, apresentaremos um caso de QSC, elencando os objetivos estruturantes e as formas de aplicação e discussão dessa estratégia de ensino em contexto de salas de aula. Assinalamos algumas considerações sobre a educação das relações étnico-raciais, bem como algumas possibilidades futuras de aplicabilidade e pesquisa em salas de aula e espaços não formais de educação científica, como em exposições museais.

\section{"Retrato molecular do Brasil" e cotas raciais: alicerces para o debate}

É recente a adoção de ações afirmativas no Brasil, marcando sobremaneira o início do século XXI. Vistas como medidas para criar igualdade de oportunidades para grupos e populações socialmente excluídas, essas ações preveem um tratamento diferenciado na sua execução, objetivando uma maior inserção na educação, no sistema de saúde e no mercado de trabalho. (SANTOS, 2012) O sistema de cotas, um exemplo de política de ações afirmativas, representa ação dirigida à correção de desigualdades raciais e sociais na educação através da reserva de vagas para negros e indígenas nas universidades públicas.

Essa temática complexa e controversa tem suscitado diversos posicionamentos, constituindo-se em questão que tem gerado apreciações divergentes no plano jurídico e acadêmico como também discussões acaloradas no plano social. (BAYMA, 2012) Como 
salienta Oliveira Filho (2009, p. 2), “[...] a adoção de ações afirmativas como estratégia de combate às diferenças socioeconômicas entre grupos racializados, uma tendência das políticas públicas governamentais nos últimos anos, é bastante suscetível a uma rejeição fundamentada em argumentos universalistas [...]".

Um exemplo destes argumentos universalistas pode ser verificado nos discursos que se baseiam na perspectiva de que no Brasil, por conta do elevado grau de miscigenação e da ausência de uma fronteira biológica entre raças, exista uma suposta igualdade racial que limita qualquer tomada de ação política com vistas a reparos socioeconômicos, como as cotas raciais. Segundo Oliveira Filho (2009, p. 2), "os racismos universalistas procuram assimilar as diferenças, mas preservam mecanismos que perpetuam a desigualdade, a dominação e a exploração", tais como os mobilizados pelo discurso "mitológico" da democracia racial, que considera a existência de relações culturais e sociais entre negros e brancos no Brasil como harmoniosas, democráticas e diluídas nas questões socioeconômicas. (MUNANGA, 2004)

O discurso da democracia racial é adversário de qualquer discurso que afirme diferenças étnicas na sociedade brasileira. (OLIVEIRA FILHO, 2009) Sobre esse processo, Joaze Bernardino (2002) afirma que a democracia racial e o ideal de embranquecimento $^{4}$ conformam grandes desafios para a implementação de ações afirmativas no Brasil. No bojo desse discurso, a miscigenação é um argumento muito utilizado para mascarar as relações de discriminação racial e impedir a implementação de políticas direcionadas aos negros. (MATTA, 2007; OLIVEIRA FILHO, 2009) Diante de tal conjuntura, os dados de Pena e colaboradores (2000) sobre a composição étnica da população brasileira podem endossar tal argumento, já que era o intuito da pesquisa destrinchar, do ponto de vista biológico, a história de formação do povo brasileiro, enfatizando a realidade sociodemográfica do país no tocante à mestiçagem. (PENA et al., 2000)

Ao longo da história, o discurso da miscigenação tem sido utilizado na defesa de uma ideia sobre inexistência de fronteiras raciais no Brasil. (BERNARDINO, 2002) Nesse contexto, os resultados de Pena e colaboradores (2000) podem ser utilizados como um modo de comprovação, de ordem científica, da inexistência de tais fronteiras raciais da população brasileira, reiterando tal discurso.

Sobre esse paralelo, Santos e Maio (2004) discutem como narrativas sobre a história da formação do povo brasileiro produzidas pela genômica, nos moldes de Pena e colaboradores (2000), vão ao encontro de um imaginário social amplamente arraigado que vê na miscigenação um elemento positivo e definidor da identidade do Brasil enquanto nação. Tal perspectiva, que se depreende da pesquisa genômica, pode se tornar peça relevante em jogos retóricos de grande relevância sociopolítica, graças à autoridade e

4 Explica o autor que, ao lado do mito da democracia racial, arquitetou-se no Brasil o ideal do branqueamento, que pressupunha uma solução para o problema racial brasileiro, em fins do século XIX e início do século $X X$, através da gradual eliminação do negro, que seria assimilado pela população branca. (BERNARDINO, 2002) 
à legitimidade de que a pesquisa científica desfruta na sociedade ocidental nos tempos atuais. (SANTOS; MAIO, 2004)

Santos e Maio (2004, 2005a) nos oferecem suportes necessários para debater tais questões relacionadas aos referidos estudos genéticos. Os autores analisaram de forma contextualizada um conjunto de debates em curso sobre a repercussão dos resultados do retrato molecular no contexto social brasileiro, examinando como a nova genética, para além de uma dimensão biológica, torna-se uma arena de disputa na qual estão presentes elementos históricos, sociais e políticos.

Os autores analisam a recepção aos estudos genômicos a partir da narrativa de diversos atores sociais. ${ }^{5}$ Entre estes, destaca-se um ativista do movimento negro, Athayde Motta, que analisa a divulgação dos resultados dos estudos de Pena e colaboradores do ponto de vista das possíveis implicações para as políticas públicas de combate ao racismo no Brasil. Para Athayde Motta, a pesquisa de Pena e colaboradores (2000) fornece um "simulacro de suporte científico" para o "mito da democracia racial", solapando as bases que fundamentam possibilidades de identidades coletivas necessárias para organizar resistências a opressões.

Uma opinião, pode-se dizer, antagônica à de Motta é representada pelo comentário entusiasta de um articulista da Folha de S. Paulo que se referiu ao trabalho como "um artigo fenomenal", "uma verdadeira aula, motivo de orgulho para a ciência brasileira". Para Elio Gaspari, o estudo "é a comprovação científica daquilo que Gilberto Freyre ${ }^{6}$ formulou em termos sociológicos", o que no seu julgamento demonstra que a genética tem grande potencialidade de reconstruir a história do povo brasileiro.

Nessa arena dos debates sobre a composição étnico-racial do Brasil, é possível encontrarmos cientistas e geneticistas tecendo comentários e fazendo julgamentos a respeito de direitos humanos e cotas raciais, com base no conhecimento científico. Um geneticista contemporâneo proeminente, Francisco Salzano (2005, p. 2, grifo nosso), questiona a validade do estabelecimento de cotas raciais em universidades avaliando tal sistema como inconstitucional, por meio do seguinte argumento:

[...] a Constituição Brasileira de 1988 , em seu artigo $5^{\circ}$, afirma que 'todos são iguais perante a lei, sem distinção de qualquer natureza', e no seu parágrafo XLII estabelece que 'a prática do racismo constitui crime inafiançável e imprescritível, sujeito à pena de reclusão, nos termos da lei'. E o que está ocorrendo, justamente, é um racismo às avessas, inclusive

5 Os argumentos mobilizados por estes atores são vinculados ideologicamente a determinadas posições políticas e compromissos sociais. O uso de narrativas objetiva apresentar o debate e chamar a atenção para a multiplicidade de opiniões e valores envolvidos na interpretação de determinados resultados de pesquisa, e não necessariamente tecer e apontar limites na construção argumentativa de cada posição, embora estejamos conscientes de que estes existam.

6 Atribui-se a Gilberto Freyre o legado de profusão da "democracia racial", convivência harmônica entre as raças, no qual o Brasil se apresenta ao mundo como um "paraíso tropical". (MATTA, 2007) 
com a instituição (vergonhosa) do apartheid: há vestibular para brancos e vestibular para negros e índios separados, incomunicáveis [...].

Para justificar sua opinião, o geneticista mobiliza dados da pesquisa de Pena e colaboradores (2000) afirmando que se $86 \%$ da população brasileira possui mais de $10 \%$ de ancestralidade africana, essa fração poderia solicitar o benefício das cotas com legitimidade. Salzano (2005) relata ainda que o fato amplamente demonstrado que a África foi o berço de toda a humanidade é suficiente para que todos os brasileiros exijam direito ao benefício.

A posição de Francisco Salzano vai de encontro às proposições do próprio Sérgio Pena, em artigo com Maria Bortolini, que questiona se a genética pode definir quem deve se beneficiar das cotas universitárias e demais ações afirmativas. Pena e Bartolini (2004, p. 16) são enfáticos em afirmar que "[...] a informação genética sobre a estrutura da população brasileira deve ser considerada apenas como um subsídio para o processo de tomada de decisões [...]". Nesse sentido, cabe destacar que o conhecimento científico, por si só, não é suficiente para apoiar a tomada de decisões sobre questões sociais.

Desse modo, na interpretação dos autores, não compete à genética fazer prescrições sociais e a definição sobre quem deve se beneficiar das cotas universitárias e das ações afirmativas no Brasil deverá ser resolvida na esfera política, levando em conta múltiplos fatores e conhecimentos, como a história do país, o sofrimento de seus vários segmentos, as análises de custo e benefício e as bases éticas da consideração moral humana. (PENA; BARTOLINI, 2004) Embora a postura dos autores seja de tentar restringir ou apresentar uma ponderação ao papel a ser exercido pelos conhecimentos genéticos nos processos de tomada de decisão política, Sérgio Pena, em entrevista à revista Ciência Hoje, avalia as ações afirmativas como um contrassenso e reforça a defesa à abolição do conceito de raça, pois:

[...] em prol de ações reparadoras, as próprias vítimas do racismo no passado queiram agora usá-lo como base para suas políticas de ação afirmativa. A única opção é eliminar o conceito de raça completamente e criar uma sociedade 'desracializada', onde as diferenças individuais sejam valorizadas [...]. (QUAL..., 2013)

Como discutido e exemplificado, no caso do debate sobre as cotas, é frequente a mobilização de argumentos universalistas e antirracialistas, reiterados pela afirmação da miscigenação. Como esclarece Oliveira Filho (2009), o tema da miscigenação e os outros temas, que constituem o que se poderia chamar de discurso da democracia racial, têm sido usados repetidamente pelos brasileiros com o objetivo de obliterar o caráter opressivo das relações raciais no Brasil e impedir a adoção de medidas estatais que diminuam a desigualdade entre negros e brancos, como a política de reserva de vagas para acessar o ensino superior. Conforme Santos e Maio (2004), percebe-se a 
emergência de associações (como "nossa mestiçagem tem um teste de DNA") que colocam os resultados da pesquisa com marcadores genéticos de ancestralidade como elementos questionadores da própria ideia de implementação de cotas raciais no Brasil.

\section{Uma QSC sobre cotas raciais}

Esta QSC foi planejada para compor intervenção em salas de aula de licenciatura em Biologia, em disciplinas como Ensino de Genética ou Ensino de Ciências, mobilizando as seguintes áreas do conhecimento: genética, história da ciência, ética, sociologia e políticas públicas. Pode ser também abordada para discutir interdisciplinarmente a pluralidade cultural e a educação das relações étnico-raciais, sendo possível utilizar também em outros cursos ou espaços não formais, desde que se faça uma adaptação da abordagem conforme análise e seleção de certos objetivos educacionais.

Quadro 1 - Caso $^{7}$ sobre genética, raça e políticas de ações afirmativas

\section{O impasse sobre implementação de cotas raciais na universidade}

Suponha que, na universidade em que você estuda, esteja ocorrendo um debate sobre a necessidade e a validade do sistema de cotas raciais. Nesta universidade, não existe um sistema de cotas e nenhuma política de reservas de vagas para negros e indígenas, como a adotada em muitas universidades federais e estaduais do Brasil e assumida como constitucional pelo Supremo Tribunal Federal (STF) em 2012.

A maioria dos professores, estudantes e funcionários da universidade está inclinada a defender que não existe necessidade de um sistema de acesso ao ensino superior que selecione as pessoas pelos critérios raciais, já que no Brasil as fronteiras raciais se diluíram diante do alto grau de miscigenação. Dentre outros argumentos contra as cotas, é recorrente a mobilização do discurso científico de que raças humanas não existem.

Diante de tal impasse, a Administração Central da Universidade decidiu convocar um plebiscito para permitir que a comunidade acadêmica decida, através do voto, sobre a implementação ou não de um sistema de cotas raciais para acesso ao ensino superior. A proposta é que esse plebiscito seja precedido por um ciclo de palestras e debates que ocorrerão durante uma semana na universidade.

Nesta conjuntura, durante uma aula em que você assistia, um grupo de estudantes negros solicita à professora alguns minutos para realizar um convite para um seminário que está próximo. $\mathrm{A}$ professora cede espaço. Durante a explanação, o grupo tece alguns comentários sobre a conjuntura racialmente desigual da sociedade e relatam as dificuldades e impossibilidades do povo negro de acessar e cursar o nível superior. Nesse momento, a professora intervém:

- Vocês poderiam expor, então, o convite? Eu preciso retomar minha aula, logo em seguida.

7 O cenário do caso nos remete a uma sala de aula com estudantes de cursos heterogêneos e de maioria racial branca. O caso apresenta uma situação hipotética de uma universidade que está discutindo cotas raciais; porém, tem como referência um conflito recente ocorrido em sala de aula da Universidade de São Paulo (USP) e divulgado na mídia eletrônica em 10 de março de 2015: <http://www.jornaldocampus.usp.br/index.php/2015/04/movimento-negro-promove-acoes-para-discutir-relacoes-raciais-na-universidade/>. Acesso em: 23 maio 2015. Para mais informações sobre o caso, ver: <https://www.youtube.com/watch?v=hG9UTnAZI6Y >. Acesso em: 22 de nov. 2015. 
Rodrigo, um dos estudantes negros do grupo, expõe enfaticamente:

- Estamos convidando todas e todos para um debate que há anos vem sendo silenciado nesta universidade, expondo a luta do nosso povo contra as infinitas desigualdades e discriminações raciais! As cotas raciais.

Nesse momento, muitos estudantes começam a emitir opinião ao mesmo tempo. Paulo, seu amigo, logo expõe em voz alta:

- Se o problema é entrar na universidade, estuda, faz um cursinho e entra!

Rafaela aproveita o momento e complementa:

- Nós sabemos que não existem raças humanas, já estudamos isso aqui na disciplina de genética. Para que uma política que privilegia uma raça? Isso é racismo da parte de vocês!

Com muita euforia na sala, Dandara, uma estudante negra da turma, tenta se posicionar:

- É só vocês olharem para o lado pra perceberem que a maioria dessa sala é branca! Isso sim é expressão do racismo, na sociedade brasileira, de maioria negra e parda. A dificuldade de acesso ao estudo pelos negros é questão histórica.

Alguns estudantes aplaudem Dandara e fazem falas de denúncia de racismo dentro da universidade. Na tentativa de acabar com a confusão instaurada, a professora solicita que o grupo realize o tal convite e finalize a explanação. Os estudantes do grupo reiteram as denúncias, dão informações sobre as palestras e debates e se retiram.

Carlos, um estudante branco, tenta mediar a discussão que continua:

- Eu não acho que nós devemos racializar, o que devemos fazer é dar oportunidades iguais a todos. Somos todos iguais, da mesma raça, humana!

A professora tenta estimular uma discussão mais qualificada, utilizando a sua própria aula para iniciar um debate sobre o tema.

Fonte: adaptado de Dias e colaboradores (2015).

\section{Questões sobre o caso}

Q1. Você, enquanto sujeito que acompanhou a discussão, com legítima oportunidade de fala no momento ou após o ocorrido, como se expressaria, na sala de aula?

Q2. Com relação à fala de Rodrigo, você reconhece a necessidade de debater tais temas na universidade? Por quê?

Q3. Levando em consideração as falas de Paulo e Dandara, os argumentos apresentados por um e por outro são suficientes para você emitir um juízo adequado a respeito deste tema? Caso não sejam, quais informações você julga necessárias para fazê-lo?

Q4. Sobre a fala de Rafaela, você concorda que não há razão para se falar de políticas públicas racialmente definidas já que a genética comprovou a inexistência de raças humanas? Por quê?

Q5. Com relação à fala de Carlos, quais ações seriam viáveis para promover oportunidades iguais para todos? Será que é possível realizar algo dessa natureza sem considerar a existência de desigualdades sociais e raciais? Justifique suas respostas. 
Q6. Você conhece outro fato, na história do Brasil, em que o discurso científico influenciou decisões sociais sobre questões raciais no país? Se sim, qual?

Q7. Como o discurso favorável ou contra as cotas poderia ser respaldado por uma ética? Quais os valores podem sustentar cada posicionamento ético relacionado ao tema?

Q8. Como os discursos referentes às cotas poderiam ser comparados a discursos de defesa da ampliação da consideração moral com relação aos seres humanos?

Levando em consideração que você e seus colegas têm o dever de emitir um voto em consonância ou não com a política de cotas nesta universidade, como você se posicionaria? A decisão deve ser justificada com base em um argumento central, elaborado com conhecimentos e referenciado com materiais necessários e relevantes para a discussão. De preferência, proponha formas de ações coletivas para contribuir com o debate que vai ocorrer na universidade, levando em consideração as consequências de diferentes interpretações dos conhecimentos sobre genética e raça para a definição de políticas públicas.

\section{Objetivos de aprendizagem da QSC segundo características tipológicas dos conteúdos}

Os objetivos educacionais desta QSC foram elaborados a partir da tipologia dos conteúdos proposta por Zabala (1998). Conforme o autor, “[...] a determinação das finalidades ou dos objetivos da educação, sejam explícitos ou não, é o ponto de partida de qualquer análise da prática [educativa]" (ZABALA, 1998, p. 29), e esse modo de determinar consiste em fazê-lo em relação às capacidades que se pretende desenvolver nos alunos.

Os propósitos estabelecidos nos objetivos educacionais são imprescindíveis para realizar a análise global do processo educacional; porém, quando nos situamos no âmbito da aula e, concretamente, numa unidade de análise válida para entender a prática que nela acontece, temos que buscar alguns instrumentos mais definidos. (ZABALA, 1998)

Nesse caso, o autor propõe os conteúdos de aprendizagem ${ }^{8}$ como instrumentos de explicitação das intenções educativas. Decidimos adotar a tipologia de Zabala (1998), para explicitar os conteúdos de aprendizagem que propomos para a aplicação da QSC apresentada na seção anterior.

8 Entendidos como tudo quanto se tem que aprender para alcançar determinados objetivos que não abrangem apenas as capacidades cognitivas, como também as motoras, afetivas, de relações interpessoais e inserção social. (ZABALA, 1998) 


\section{Conceituais}

- Fatos: a implantação de um sistema de cotas raciais, a qual tem sido debatida socialmente no Brasil com mais intensidade no século XXI; o discurso científico que tem sido empregado no âmbito de debates sociais, a exemplo daqueles a respeito da implantação de políticas públicas de ações afirmativas; os discursos racistas comuns na história das ciências naturais e biomédicas; o mito da democracia racial como discurso obliterador de conquista de direitos raciais no Brasil; os mitos relacionados ao cientificismo;

- Conceitos: raça biológica e raça como construção social; espécie; populações; alterização; racismo; evolução; polimorfismo; marcadores genéticos; cientificismo;

- Princípios: frequências regionais de haplogrupos mitocondriais e do cromossomo Y como indicativo de ancestralidade; direito a um acesso qualificado aos bens sociais e políticos; ampliação do direito à diferença como um dos pilares dos direitos sociais.

\section{Procedimentais}

- Procedimentos: desenvolver a capacidade argumentativa; interpretar os resultados de estudo de identificação das proporções genéticas de ancestralidade africana, europeia e ameríndia;

- Técnicas: compreender como são empregadas as análises do DNA mitocondrial, do cromossomo Y e do DNA nuclear; realizar análise de discurso científico sobre relações raciais;

- Métodos: comparar diferentes discursos e vínculos ideológicos e políticos.

\section{Atitudinais}

- Valores: consideração moral das diferentes raças, etnias e gêneros; valor intrínseco e extrínseco de sujeitos; convivência democrática e igualitária entre diferentes grupos com consciência dos mecanismos de poder que permeiam as relações sociais;

- Normas: comunicação intersubjetiva entre sujeitos como aspecto central da elaboração e constante transformação dos princípios ético-morais que regem os conflitos (MARQUES, 2010); consideração sobre a Lei $n^{\circ}$ 12.711/2012 e o Decreto $\mathrm{n}^{0} 7.824 / 2012$, que definem as condições gerais de reservas de vagas para negros e indígenas em universidade públicas brasileiras, além da legislação que criminaliza os atos de discriminação ou preconceito de raça, cor, etnia, religião ou procedência nacional (Lei $\left.{ }^{0} 7.716 / 1989\right)$;

- Atitudes: respeito às diferentes raças e etnias socialmente construídas e solidariedade com as minorias sociais, políticas e econômicas e suas formas de resistência; conduzir debate qualificado sobre política de ações afirmativas; criticar, em um debate público, a função ideológica do discurso científico sobre raças na 
geração de processos de alterização e exclusão; e atuar na superação das desigualdades sociais e raciais.

\section{Meios para aplicação e discussão da QSC no ensino}

Os fatores que influenciam as relações entre os processos sociais de alterização, exclusão e marginalização de grupos humanos e os discursos ou práticas tecnocientíficas aparecem submersos dentro de uma matriz complexa de relações culturais profundamente influenciadas por forças históricas, socioeconômicas, políticas e ideológicas (SÁNCHEZ-ARTEAGA; SEPÚLVEDA; EL-HANI, 2013), como é o caso que se propõe discutir com esta QSC.

É perceptível como o debate sobre políticas de ações afirmativas está imerso numa conjuntura de conflitos, nos quais conhecimentos científicos são frequentemente utilizados para interpretar desigualdades sociais e culturais e meios para reparação das mesmas. Sendo assim, a condução dessa QSC deve levar em consideração essa teia de complexas relações de poder e estimular sua compreensão e crítica a partir da análise de valores e ideologias envolvidos na situação problema.

Uma forma viável para problematizar esse conjunto de fatores é esclarecer as formas possíveis de relação entre os resultados de Pena e colaboradores (2000) com temas e ideologias que constituem o discurso da democracia racial, como a miscigenação, a mestiçagem e o branqueamento, através das reações e análises de pesquisadores e atores sociais sobre a questão das políticas de ações afirmativas. Para tal intento, podem ser utilizados como subsídio para o debate em sala alguns trabalhos e textos que analisam e/ou representam essas reações, a exemplo de Bernardino (2002), Santos e Maio (2004, 2005a, 2005b), Pena e Bortolini (2004), entre outros. ${ }^{9}$

Podem ser utilizados ainda outros recursos que mobilizam diversos argumentos nesse sentido, como vídeos disponíveis na internet, a exemplo da audiência pública sobre cotas raciais nas universidades brasileiras, realizada em $2010 ;{ }^{10}$ do debate no Superior Tribunal Federal sobre constitucionalidade das cotas raciais em 2012;11 do documentário Raça humana, que revela os bastidores das cotas raciais na Universidade de Brasília (UnB), ${ }^{12}$ e de fragmento do documentário USP 7\% que mostra a mobilização em favor da cotas raciais na maior universidade do Brasil. ${ }^{13}$ Além de vídeos, outros veícu-

9 Outra referência que pode ser utilizada é a seção Espaço Aberto do número 23 da revista Horizontes Antropológicos, a qual aborda discussão sobre cotas raciais a partir da enunciação de intelectuais sobre um artigo de Marcos Chor Maio e Ricardo Ventura Santos. Conforme proposta dos editores, esse debate promove a relação entre reflexões acadêmicas e a ação política, expandindo o seu interesse para além do tema propriamente dito. (TEIXEIRA; STEIL, 2005)

10 Ver em: <https://www.youtube.com/watch?v=|BfsV3tH0T0 $>$.

11 Ver em: <https://www.youtube.com/watch?v=D_6JXx1_Coc>.

12 Ver em: <https://www.youtube.com/watch?v=y_dbLLBPXLo>.

13 Ver em: <https://www.youtube.com/watch?v=WAWkE2bU0QM>. 
los importantes, como sites, jornais e revistas virtuais, reúnem informações pertinentes para o debate sobre cotas raciais. ${ }^{14}$

Essas referências devem balizar as discussões em sala sobre o uso de conhecimentos científicos na orientação de decisões políticas e sociais, assim como para gerar exclusão e desigualdade. Nesse percurso discursivo, podem ser explorados também alguns fatos emblemáticos de alterização e racismo ao longo da história da ciência, além da construção do próprio conceito de raças humanas pelas ciências naturais. Para subsidiar tal abordagem, propomos utilizar alguns princípios elaborados por Sánchez Arteaga e El-Hani (2012) para intervenções educativas sobre racismo científico e relações CTSA. ${ }^{15}$ Para os autores, a abordagem do racismo científico do século XIX, na Europa e no Brasil, pode desenvolver uma forma de análise de como os discursos da biologia desempenharam uma função ideológica sobre as relações inter-raciais no passado e, nesse sentido servem como base para professores e estudantes analisarem as funções ideológicas do conhecimento biológico contemporâneo.

Essa perspectiva de desenvolvimento da QSC em sala de aula corrobora a proposta de Hodson (2004) que estabelece quatro níveis de sofisticação de um currículo voltado para ação sociopolítica, baseado na abordagem da educação CTSA. Diante deste primeiro cenário de discussão, acreditamos que a QSC tem potencialidades de estimular os seguintes níveis:

- $\quad$ percepção da dependência cultural da ciência e da tecnologia; e

- percepção que o desenvolvimento científico e tecnológico ocorre a partir de interesses particulares, com benefícios para alguns em detrimento de outros diante de relações da distribuição de riquezas e poder. (HODSON, 2004)

No percurso de aplicação da QSC, pode-se pensar em dois momentos específicos para intervenção, conforme objetivos educacionais pretendidos. $\mathrm{O}$ primeiro momento, composto de leitura do caso e resposta às primeiras seis questões, com posterior debate ampliado sobre as temáticas e conceitos identificados. Durante esta etapa, pode ser estimulada a prática de pesquisa bibliográfica pelos estudantes para melhor fundamentar a discussão, além de permitir maior contato e apropriação das temáticas relacionadas.

14 Ver em: Jornal do Campus da USP <http://www.jornaldocampus.usp.br/>; Portal Geledés <http:// www.geledes.org.br/\#gs.U=W6kpA>; Revista Äfrica e Africanidades <http://www.africaeafricanidades.com.br/>; Revista da Associação Brasileira de Pesquisadores(as) Negros(as) <http://www. abpn.org.br/Revista/index.php/edicoes/search/results>; Blog do Negro Belchior na Carta Capital $<$ http://negrobelchior.cartacapital.com.br/>; Anistia Internacional Brasil: <https://anistia.org.br/?no-high>; Carta Educação <http://www.cartaeducacao.com.br/>. Acesso em: 22 nov. 2015.

15 Os autores ressaltam a necessidade e importância de trabalhar em intervenções educativas os discursos biológicos sobre raças, incluindo as implicações da pesquisa genética contemporânea que põe em questão a própria existência de raças na espécie humana. 
Já indicamos algumas fontes e referências para estimular a compreensão sobre os vínculos políticos e ideológicos de determinados discursos científicos; porém, se faz necessário mediar outras reflexões pertinentes à situação-problema, tais como referentes aos dados sobre desigualdades raciais no Brasil e à dificuldade de acesso da população negra e indígena a direitos sociais mínimos.

Sobre este tema, sugerimos utilizar, por exemplo, pesquisa de Henriques (2001) e o Relatório anual das desigualdades raciais no Brasil 2009-2010 ${ }^{16}$ o que permitirá um diálogo a respeito dos mecanismos sociais e razões históricas que obstruem, no Brasil, a mobilidade socioeconômica ascendente das pessoas negras e etnicamente distintas do padrão eurocêntrico. Nessa questão, é importante ainda debater sobre o acesso desigual ao espaço geográfico, disponibilizando para análise as próprias condições de mobilidade urbana da população menos favorecida em termos socioeconômicos, de maioria negra, e a territorialidade periférica destas. Além disso, pode-se trazer à tona as diversas formas de cerceamento dos diretos sociais básicos para esta parcela da população que perduram desde o pós-abolição ${ }^{17}$ e, dessa maneira, dialogar sobre a ideia de colonialidade no padrão de poder hoje hegemônico, ${ }^{18}$ como forma de conjeturar processos de dominação e relações de poder ao longo da história. Outro recurso que pode ser utilizado para aprofundar facetas da desigualdade racial no Brasil é o conjunto de dados sobre violência contra juventude negra dispostos em Brasil (2015), que agrega dados relativos às dimensões consideradas centrais na determinação da vulnerabilidade dos jovens à violência, tais como: taxa de frequência à escola, escolaridade, inserção no mercado de trabalho, taxa de mortalidade por causas internas, taxa de mortalidade por causas violentas, valor do rendimento familiar médio mensal, entre outros. Em termos gerais, são destaques nesse material as elevadas taxas de violência observadas no país contra adolescentes e jovens entre 12 e 29 anos de idade, em especial jovens negros, que, em 2013, foram 18,4\% mais encarcerados e 30,5\% mais vítimas de homicídios dos que os jovens brancos.

A prevalência de jovens negros serem mais vítimas de assassinatos do que jovens brancos é uma tendência nacional: em média, jovens negros têm 2,5 mais chances de morrer do que jovens brancos no país. (BRASIL, 2015) Estimular a crítica sobre essa conjuntura homicida sobre a juventude negra ${ }^{19}$ e os fatores sociais, econômicos

16 Disponível em: <http://www.palmares.gov.br/wp-content/uploads/2011/09/desigualdades_raciais_2009-2010.pdf>. Acesso em: 20 ago. 2017.

17 Para mais informações sobre, ver o livro As políticas públicas e a desigualdade racial no Brasil: 120 anos após a abolição, publicado pelo Instituto de Pesquisa Econômica Aplicada. Disponível em: <http://www.ipea.gov.br/portal/images/stories/Livro_desigualdadesraciais.pdf>. Acesso em: 20 ago. 2017.

18 Para Quijano (2005), um dos eixos fundamentais do padrão de poder mundial é a classificação social da população mundial de acordo com a ideia de "raça", uma construção mental que expressa a experiência básica da dominação colonial e que desde então permeia as dimensões mais importantes do poder mundial, incluindo sua racionalidade específica, o eurocentrismo.

$19 \mathrm{Na}$ interpretação de muitos atores políticos e do movimento negro, vivemos efetivamente um genocídio da juventude negra, que envolve todas as políticas estatais que sistematicamente têm 
e políticos em voga é extremamente necessário por dimensionar em última análise as consequências nefastas e inadmissíveis do racismo institucionalizado e das diversas políticas estatais no gerenciamento de mortes de uma parcela significativa da juventude brasileira.

Um outro aspecto para condução da QSC é esclarecer sobre questões metodológicas e procedimentais da pesquisa de Pena e colaboradores (2000), para incentivar a compreensão sobre os dados e conhecimentos teóricos que a genética se baseia para definir a composição étnico-racial da população brasileira a partir de marcadores moleculares de ancestralidades e concluir sobre a inexistência de raças do ponto de vista biológico. Propõe-se, sobre esse aspecto, o uso do trabalho original de Pena e colaboradores (2000), além de trabalhos originais da equipe de pesquisa com apresentação dos resultados em pormenores para a comunidade científica. (ALVES-SILVA et al., 2000; CARVALHO-SILVA et al., 2001; PARRA et al., 2003)

Num segundo momento de aplicação da QSC, grupos de estudantes deverão levantar possíveis argumentos para sustentar a escolha de decisão diante da questão sete, que aponta uma problemática a ser resolvida. Podem ser promovidos espaços para diálogo com o(a) professor(a) da disciplina culminando em um momento ampliado de apresentação pública das propostas desenvolvidas e dos argumentos que as sustentam. Dependendo do contexto didático e da disponibilidade de tempo hábil para o desenvolvimento da estratégia pedagógica, pode-se incluir como demanda de pesquisa para qualificar as respostas, a fundamentação teórica de estratégias de argumentação nas discussões em grupos. ${ }^{20}$

Estas etapas fundamentarão o nível três, do currículo proposto por Hodson (2004): desenvolvimento de próprio ponto de vista dos estudantes e de posições valorativas, que iniciam com o fomento da autoestima e do bem-estar pessoal, e estende-se ao respeito dos direitos de outros indivíduos, à confiança mútua, à busca de justiça, à tomada de decisão cooperativa e criativa e à resolução de conflitos entre indivíduos, dentro e entre comunidades. A proposição desse nível de educação dialoga profundamente com as diretrizes pedagógicas e princípios políticos de uma educação das relações étnico-raciais:

[...] atividades curriculares ou não, em que: - promovam-se oportunidades de diálogo em que se conheçam, se ponham em comunicação diferentes sistemas simbólicos e estruturas conceituais, bem como se busquem formas de convivência respeitosa, além da construção de projeto de sociedade em que todos se sintam encorajados a expor, defender sua especificidade étnico-racial e a buscar garantias para que todos o façam; - sejam incen-

impacto negativo na qualidade de vida da população negra. O genocídio diz respeito a todo ato que visa destruir, matar, limitar a reprodução física, cultural e social de um determinado grupo em desvantagem social em relação aos outros grupos em determinada sociedade. (FEFFERMANN, 2013)

Por exemplo, Toulmin (2006). 
tivadas atividades em que pessoas de diferentes culturas interatuem e se interpretem reciprocamente, respeitando os valores, visões de mundo, raciocínios e pensamentos de cada um [...]. (BRASIL, 2004, p. 11)

Além desta diretriz, o caso em questão pode fomentar outros princípios e demandas de uma educação das relações étnico-raciais, como os processos de construção de identidades raciais, as estratégias de combate a preconceitos e discriminações e o fomento de consciências dos direitos raciais e sociais.

A tônica do racismo no debate sobre cotas raciais e a mobilização de discursos científicos antirracialistas no combate às políticas de ações afirmativas são, talvez, aspectos da proposta geral desta QSC que mais dialoguem com demandas de uma educação das relações étnico-raciais no sentido de potencializar estratégias e ações educativas de combate ao racismo e às discriminações; tais demandas estão expressas nos documentos legais e nas diversas proposições políticas do movimento negro para a educação brasileira. $^{21}$

Ao dimensionar os alicerces e componentes do racismo nesse debate, incluindo seus discursos, ideologias e consequências sociais, o(a) professor(a) pode facilmente estabelecer relações com expressões e ações racistas no cotidiano dos(a)s estudantes e traçar metas e propostas para superação destas, implicando, segundo as propostas de Gomes (2012), na formação de subjetividades inconformistas diante das práticas racistas e no conhecimento teórico-conceitual mais aprofundado sobre as questões afro-brasileiras.

Outra forma de trabalhar relações étnico-raciais a partir do caso em questão é discutir sobre o sentido dos testes de ancestralidade na construção de identidades, ou ainda sobre a influência do discurso de desinvenção das raças do ponto de vista biológico em processos identitários coletivos que se forjam na luta antirracista e na defesa de políticas de ações afirmativas. Um aspecto importante a ser discutido, nesse sentido, é problematizar se marcadores moleculares podem definir quem deve ser assistido(a) por políticas com recorte racial (PENA; BORTOLINE, 2004; SANTOS; BORTOLINE; MAIO, 2005/2006; SANTOS; MAIO, 2005a) ou ainda se dados genéticos contribuem para reforçar identidades minoritárias ou para negação e relativização destas. Nesse debate é importante ressaltar a contribuição das políticas afirmativas como mecanismos capazes de corrigir o reconhecimento distorcido e a estigmatização que têm sido projetados so-

21 Os principais dispositivos legais que fundamentam tal perspectiva educacional são: Lei 9.394, de 9 de dezembro de 1996, relacionada às alterações recentes: Lei 10.639, de 9 de janeiro de 2003 e Lei 11.645, de 10 de março de 2008; a Resolução do Conselho Nacional de Educação - CNE/ CP- 01/2004, que aprovou as Diretrizes Curriculares Nacionais para a Educação das Relações Étnico-raciais e para o Ensino de História e Cultura Afro-Brasileira e Africana (BRASIL, 2004), e o Parecer CNE/CP 03/2004, que fundamenta tais diretrizes; Plano Nacional de Implementação das Diretrizes Curriculares Nacionais para a Educação das Relações Étnico-raciais e para o Ensino de História e Cultura Afro-brasileira e Africana. (BRASIL, 2009) 
bre a população negra, provocando, assim, uma reviravolta identitária ao permitir uma atribuição de um valor positivo à classificação social do negro e do indígena. ${ }^{22}$

Nesse quesito, é pertinente problematizar a polêmica entre a desconstrução do conceito biológico de raça e a permanência desse conceito enquanto categoria de distinção, classificação e discriminação social, fato central na argumentação sobre a defesa e o combate às políticas de ações afirmativas e em todo debate sobre a questão racial no Brasil. É importante explicitar que a categoria de raça que opera no imaginário da população e produz discursos racistas é ainda a ideia de raça produzida pela ciência moderna nos séculos XIX e XX. Essa perspectiva de discussão pode ser trabalhada a partir da proposição das diretrizes para educação das relações étnico-raciais, as quais entendem o conceito de raça como construção social forjada nas tensas relações entre brancos e negros, muitas vezes simuladas como harmoniosas, nada tendo a ver com o conceito biológico de raça cunhado no século XVIII e hoje sobejamente superado. (BRASIL, 2004) Essa ideia reitera os escritos de Guimarães (1999, p. 153) sobre a necessidade de teorizar as "raças" como o que elas são, ou seja, "[...] construtos sociais, formas de identidade baseadas numa ideia biológica errônea, mas eficaz, socialmente, para construir, manter e reproduzir diferenças e privilégios”. Nessa discussão, é também importante entender a relação do ideário antirracialista com uma política de negação do racismo como fenômeno social, buscando compreender como a redução do antirracismo ao antirracialismo sustentou a necessidade de retomada do conceito social de raça na história. (GUIMARÃES, 1999; PENA; BIRCHAL, 2006; SCHUCMAN, 2010)

Por fim, com a apresentação das propostas e dos argumentos, deve ser encaminhada uma discussão que mobilize os conhecimentos trabalhados e desenvolvidos para o nível quatro, do currículo proposto por Hodson (2004): preparo e realização da ação sociopolítica. Nesse sentido, pode-se iniciar uma avaliação ampliada sobre as ações coletivas que cada grupo elencou como forma de contribuição para o debate que está ocorrendo na universidade, encaminhada no sentido de caracterizar as ações que conseguem responder às demandas sociais/raciais em estreita relação com projetos de sociedade, formas de dominação e propostas de transformação social.

A depender do contexto que essa estratégia de ensino seja desenvolvida, para refletir sobre a realidade social local e avaliar a pertinência de atuação no sentido de promoção de espaços para discussão sobre políticas de ações afirmativas, podemos propor uma plataforma de debates com representantes políticos, institucionais e movimentos sociais, que tenha como diretriz a promoção de discussão e encaminhamentos como forma de refletir e transformar tais políticas, impactando, assim, a realidade de cada universidade.

Como resolução desta QSC, pode-se pensar ainda numa atividade pública e didática como produto, na qual seja divulgada e problematizada, de forma mais abrangente e contextualizada, a interrelação que se estabelece entre conhecimentos científicos e va-

22 Para essa discussão, ver Bernardino (2002). 
riadas demandas sociais e políticas em torno da questão racial. Uma forma para colocar em prática tal proposta pode ser baseada em experiências de ensino do nosso grupo de pesquisa realizadas desde 2011 sobre ciência e raça, ${ }^{23}$ cujas motivações iniciais estão relacionadas à reflexão sobre os riscos potenciais que discursos teóricos e práticas das tecnociências podem apresentar para promover alterização, exclusão e marginalização de determinados grupos sociais e culturais. (DIAS et al., 2014)

\section{Considerações e perspectivas}

Problematizar a questão étnico-racial no âmbito do ensino de ciências e biologia a partir das controvérsias sociocientíficas é colaborar com a reflexão em salas de aula, e fora delas, sobre a compreensão da natureza do conhecimento científico, entendendo a ciência como uma atividade social e cultural imersa em contextos históricos nos quais permeiam valores, crenças e ideologias que repercutem na construção e no consequente uso dos seus aportes teóricos.

Neste caso, em especial, trata-se de contribuir com o debate sobre o papel que a mobilização do conhecimento científico pode exercer em processos de decisões políticas contemporâneas que fundamentam alterização, racismo e marginalização de determinados grupos humanos. Dessa forma, tal perspectiva reitera a necessidade de superar visões de ciência descontextualizada, a problemática e linear, tão frequentemente abordadas entre professores e estudantes nas escolas.

Em vista disso, assumimos que a QSC apresentada pode contribuir com a formatação de propostas para trabalhar com tais alicerces teórico-metodológicos em intervenções didáticas de ciências e biologia, colaborando com a formação de professores nesse sentido e reduzindo, assim, uma lacuna existente na literatura sobre construção de práticas educativas voltadas para a questão étnico-racial (GOMES, 2003; VERRANGIA; SILVA, 2010) e sobre formulação de estratégias de ensino com enfoque CTSA. (ZEIDLER; NICHOLS, 2009)

O processo de implementação desta proposta didática pode encontrar algumas limitações e dificuldades, ao exigir do(a) professor(a) uma apropriação teórica e discursiva ampla e diversa, sobre temáticas e conceitos normalmente ausentes e/ou silenciados nos currículos de licenciatura em Biologia, por exemplo. Vale ressaltar, ainda, a dificuldade em realizar um tratamento adequado da questão racial brasileira, tão múltipla e polêmica, e por envolver questões notadamente subjetivas e identitárias.

23 Fruto de uma construção coletiva que envolve pesquisadores do Laboratório de Ensino, Filosofia e História da Biologia (Instituto de Biologia da Universidade Federal da Bahia) e do Grupo Colaborativo de Pesquisa em Ensino de Ciências (Departamento de Educação da Universidade Estadual de Feira de Santana), juntamente com estudantes de graduação em Ciências Biológicas e do Programa de Pós-graduação em Ensino, Filosofia e História das Ciências (PPGEFHC). Essa articulação permitiu a construção de oito edições de uma exposição itinerante que aborda de forma interativa temáticas que versam sobre ciência, raça, literatura e sociedade. 
A proposição desta QSC só terá sua potencialidade explorada quando concretizar-se como prática educativa em salas de aula ou outros espaços educativos, podendo ser devidamente investigada a partir da colaboração com pesquisadores do tema e da abordagem curricular CTSA a partir de QSC. Diante do que defendemos e tentamos argumentar neste capítulo, o esforço de substanciar práticas educativas com tal perspectiva é derivado de diversas contribuições teóricas, políticas e institucionais nas quais reside responsabilidade conjunta de pesquisadores, professores e gestores públicos na consolidação de uma educação que questione as relações de dominação e poder, promova o exercício de cidadania de caráter emancipatório, com base numa agenda política.

\section{Referências}

ALVES-SILVA, J. et al. The ancestry of brazilian mt DNA lineages. American Journal of Human Genetics, Chicago, v. 67, n. 2, p. 444-461, 2000.

BAYMA, F. Reflexões sobre a constitucionalidade das cotas raciais em universidades públicas no Brasil: referências internacionais e os desafios pós-julgamento das cotas. Ensaio: Avaliação e Políticas Públicas em Educação, Rio de Janeiro, v. 20, n. 75, p. 325346, 2012.

BERNARDINO, J. Ação afirmativa e a rediscussão do mito da democracia racial no Brasil. Estudos Afro-Asiáticos, Rio de Janeiro, ano 24, n. 2, p. 247-273, 2002.

BRASIL. Índice de vulnerabilidade juvenil à violência e desigualdade racial 2014. Brasília, DF, 2015. Série Juventude Viva. Disponível em: <http://unesdoc.unesco.org/ images/0023/002329/232972POR.pdf>. Acesso em: 3 dez. 2015.

BRASIL. Ministério da Educação. Conselho Nacional de Educação. Diretrizes Curriculares Nacionais para a educação das relações étnico-raciais e para o ensino de história e cultura afro-brasileira e africana. Brasília, DF, 2004. Disponível em: <http:// portal.mec.gov.br/cne/arquivos/pdf/003.pdf>. Acesso em: 14 nov. 2014.

BRASIL. Ministério da Educação. Plano nacional das diretrizes curriculares nacionais para a educações das relações étnico-raciais e para o ensino de história e cultura afrobrasileira e africana. Brasília, DF, 2009.

CARVALHO-SILVA, D. R. et al. The phylogeography of Brazilian Y-chromosome lineages. American Journal of Human Genetics, Chicago, v. 68, n. 1, p. 281-286, 2001.

DIAS, T. L. S. et al. As contribuições da exposição ciência, raça e literatura para a educação das relações étnico-raciais. Revista da SBEnBio, Campinas, v. 7, p. 7226-7238, 2014.

DIAS, T. L. S. et al. Genética, raça e políticas de ações afirmativas a partir de questões sociocientíficas. In: SIMPÓSIO NACIONAL DE TECNOLOGIA E SOCIEDADE, 6., 2015, Rio de Janeiro. Anais... Rio de Janeiro: CCMN/UFRJ, 2015. p. 1-17.

FEDIGAN, L. M. The changing role of women in models of human evolution. Annual Review of Anthropology, [S.1.], v. 15, p. 25-66, 1986. 
FEFFERMANN, M. A luta contra o genocídio da juventude negra: reflexões sobre a realidade brasileira. In: CONGRESO DE LA ASOCIACIÓN LATINOAMERICANA DE SOCIOLOGÍA, 29., 2013, Santiago. Anais... Santiago: Asociación Latinoamericana de Sociología, 2013. Disponível em: <http://actacientifica.servicioit/biblioteca/pn/ PN33/P_Fefferman.pdf>. Acesso em: 12 dez. 2015.

GIL-PÉREZ, D. et al. Para uma imagem não deformada do trabalho científico. Ciência \& Educação, Bauru. v. 7, n. 2, p. 125-153, 2001.

GOMES, N. L. Cultura negra e educação. Revista Brasileira de Educação, Belo Horizonte, n. 23, p. 75-85, 2003.

GOMES, N. L. Práticas pedagógicas de trabalho com relações étnico-raciais na escola na perspectiva da Lei $n^{o}$ 10.639/03. Brasília: MEC: Unesco, 2012.

GUIMARÃES, A. S. A. Raça e os estudos de relações raciais no Brasil. Novos Estudos CEBRAP, São Paulo, n. 54, p. 147-156, 1999.

HARAWAY, D. J. Ciencia, cyborgs y mujeres: la reinvención de la naturaleza. Madrid: Cátedra, 1991.

HENRIQUES, R. Desigualdade racial no Brasil: evolução das condições de vida na década de 90. Rio de Janeiro: IPEA, 2001. (Texto para Discussão, 807).

HODSON, D. Going beyond STS: towards a curriculum for sociopolitical action. The Science Education Review, Warwick, v. 3, n. 1, p. 2-7, 2004.

MARQUES, A. C. S. Ética do discurso e deliberação mediada sobre a questão das cotas raciais. Líbero, São Paulo, v. 13, n. 26, p. 75-90, 2010.

MARTÍNEZ PÉREZ, L. F. A abordagem de questões sociocientíficas na formação continuada de professores de Ciências: contribuições e dificuldades. 2010. 351 f. Tese (Doutorado em Educação para a Ciência) - Faculdade de Ciências, Universidade Estadual Paulista, Bauru, 2010.

MARTÍNEZ PÉREZ, L. F.; CARVALHO, W. L. P. Contribuições e dificuldades da abordagem de questões sociocientíficas à prática de professores de ciências. Educação e Pesquisa, São Paulo, v. 38, n. 3, p. 728-742, 2012.

MATTA, L. G. da. Da democracia racial à ação afirmativa: a política de cotas para negros. Revista Jurídica da Faminas, Muriaé, v. 3, n. 1, p. 59- 72, 2007.

MUNANGA, K. Uma abordagem conceitual das noções de raça, racismo, identidade e etnia. In: BRANDÃO, A. A. P. (Org.). Cadernos Penesb. Niterói: Ed. UFF, 2004. p. 15-34.

OLIVEIRA FILHO, P. A mobilização do discurso da democracia racial no combate às cotas para afrodescendentes. Estudos de Psicologia, Campinas, v. 26, n. 4, p. 429-436, 2009.

PARRA, F. C. et al. Color and genomic ancestry in Brazilians. Proceedings of the National Academy of Sciences, New York, v. 100, n. 1, p. 177-82, 2003. 
PENA, S. D. J. et al. Retrato molecular do Brasil. Ciência Hoje, São Paulo, v. 27, n. 159, p. 16-25, 2000.

PENA, S. D. J.; BORTOLINI, M. C. Pode a genética definir quem deve se beneficiar das cotas universitárias e demais ações afirmativas? Estudos Avançados, São Paulo, v. 18, n. 50, p. 31-50, 2004.

PENA, S. D. J.; BIRCHAL, T. S. A inexistência biológica versus a existência social de raças humanas: pode a ciência instruir o etos social? Revista USP, São Paulo, n. 68, p. 10-21, 2005-2006.

QUAL a sua raça/cor? Ciência Hoje, Rio de Janeiro, 13 maio 2013. Disponível em: <http://www.cienciahoje.org.br/noticia/v/ler/id/1934/n/qual_a_sua_raca_cor/Post_ page/1166>. Acesso em: 10 jun. 2015.

QUEROL, M. A. Adán y Darwin. Madrid: Síntesis, 2001.

QUIJANO, A. Colonialidade do poder, eurocentrismo e América Latina. In: LANDER, E. (Org.). A colonialidade do saber: eurocentrismo e ciências sociais - perspectivas latino-americanas. Buenos Aires: CLACSO, 2005. p. 227-278.

SALZANO, F. M. Raça, racismo e direitos humanos. Horizontes Antropológicos, Porto Alegre, v. 11, n. 23, p. 225-227, 2005.

SANTOS, J. T. dos. Ações afirmativas e educação superior no Brasil: um balanço crítico da produção. Revista brasileira de estudos pedagógicos, Brasília, DF, v. 93, n. 234, p. 401422, 2012.

SANTOS, R. V.; MAIO, M. C. Qual "retrato do Brasil"? Raça, biologia, identidades e política na era da genômica. Mana, Rio de Janeiro, v. 10, n. 1, p. 61-95, 2004.

SANTOS, R. V.; MAIO, M. C. Antropologia, raça e os dilemas das identidades na era da genômica. História, Ciências, Saúde - Manguinhos, Rio de Janeiro, v. 12, n. 2, p. 447 468, 2005a.

SANTOS, R. V.; MAIO, M. C. Política de Cotas Raciais, os "olhos da sociedade" e os usos da antropologia: o caso do vestibular da Universidade de Brasília (UNB). Horizontes Antropológicos, Porto Alegre, v. 11, n. 23, p. 181-214, 2005b.

SANTOS, R. V.; BORTOLINE, M. C.; MAIO, M. C. No fio da navalha: raça, genética e identidades. Revista USP, São Paulo, n. 68, p. 22-35, 2005/2006.

SANTOS, W. L. P. dos; MORTIMER, E. F. Tomada de decisão para ação social responsável no ensino de ciências. Ciência e Educação, Bauru, v. 7, n. 1, p. 95-111, 2001.

SANTOS, W. L. P. dos; MORTIMER, E. F. Uma análise de pressupostos teóricos da abordagem C-T-S (Ciência - Tecnologia - Sociedade) no contexto da educação brasileira. Ensaio - Pesquisa em Educação em Ciências, Belo Horizonte, v. 2, n. 2, p. 1-23, 2002.

SÁNCHEZ-ARTEAGA, J. M. S. La razón salvaje. La lógica del dominio: tecnociencia, racismo y racionalidad. Madrid: Lengua de Trapo, 2007. 
SÁNCHEZ-ARTEAGA, J. M.; EL-HANI, C. N. Othering processes and STS curricula: From nineteenth century scientific discourse on interracial competition and racial extinction to othering in biomedical technosciences. Science \& Education, Dordrecht, v. 21, n. 5, p. 607-629. 2012.

SÁNCHEZ-ARTEAGA, J. M.; SEPÚLVEDA, C.; EL-HANI, C. N. Racismo científico, procesos de alterización y enseñanza de ciencias. Magis, Revista Internacional de Investigación en Educación, Rio de Janeiro, v. 6, n. 12, p. 55-67, 2013.

SCHIEBINGER, L. Has feminism changed science? Signs: journal of women in culture and society, Chicago, v. 25, n. 4, p. 1171-1175, 2000.

SCHUCMAN, L. V. Racismo e antirracismo: a categoria raça em questão. Psicologia Política, São Paulo, v. 10, n. 19, p. 41-55, 2010.

TEIXEIRA, S. A.; STEIL, C. A. Introdução ao debate sobre cotas. Horizontes Antropológicos, Porto Alegre, v. 11, n. 23, p. 179-180, 2005.

TOUlMiN, S. E. Os usos do argumento. 2. ed. São Paulo: Martins Fontes, 2006.

VERRANGIA, D.; SILVA, P. B. G. Cidadania, relações étnico-raciais e educação. Educação \& Pesquisa, São Paulo, v. 36, n. 3, p. 705-718, 2010.

VERRANGIA, D. Educação e diversidade étnico-racial: o ensino e a pesquisa em caso. Interacções, Lisboa, v. 10, n. 31, p. 2-27, 2014.

ZABALA, A. A prática educativa: como ensinar. Porto Alegre: Artmed, 1998.

ZEIDLER, D. L.; NICHOLS, B. H. Socioscientific issues: theory and practice. Journal of Elementary Science Education, New York, v. 21, n. 2, p. 49-58, 2009. 